\title{
Multi Soil Layering (MSL) System for Treatment of Noodle Industry Wastewater
}

\author{
Refilda, Syukrya Ningsih, Matlal Fajri Alif, Zilfa and Rahmiana Zein*
}

\begin{abstract}
Multi-soil-layering (MSL) systems consist of soil mixture layers (SML) such as charcoal, sawdust, iron scraps, volcanic soil with composition (10:10:5:75) and permeable zeolite layers (PL) were constructed in $50 \mathrm{~cm}$ (width) $\times 15 \mathrm{~cm}$ (depth) $\times 50 \mathrm{~cm}$ (height) an acrylic box like the brick pattern for removal of phosphate, nitrite, nitrate, oil and grease from noodle industry wastewater. The variations of the wastewater flow rate in the system were $10,20,40$, and $80 \mathrm{~mL}$ min-1 with two processes aeration and non-aeration conditions were evaluated. The results revealed that the aeration assists the removal efficiency of phosphate, nitrite, nitrate, oil and grease on MSL system at flow rate $10 \mathrm{mLmin}-1$ were $99.43 \%, 83.65 \%$, $79.43 \%$ and $100 \%$, respectively.
\end{abstract}

Keywords- multi-soil-layering (MSL) system, phosphate, nitrite, nitrate, oil and grease removal.

\section{Introduction}

Multi Soil Layering (MSL) is a method that can be used for wastewater treatment system designed for enhances the inherent ability of the soil to purify wastewater. The MSL system has high treatment efficiency for municipal wastewater, livestock wastewater and polluted river water treatment that has been reported [1,2,3], these authors reported the characteristics of the MSL system and its applicability to various types of wastewater or polluted water treatments. The MSL system is known to minimize of cost treatment, requiring only a small land, is ideal for urban areas in developing countries [2] it is simple in terms of operation and control, as well as environmentally friendly, because it can be developed mainly from locally available resources, such as soil, sawdust, iron particles, coconut charcoal, and gravel or other rocks of homogeneous sizes that allow a high hydraulic loading rate [4]. The MSL system is effective for the prevention of clogging which are the main constraints in the conventional soil-based wastewater treatment systems [5].

The MSL system has several advantages, among others, were able to reduce the value of BOD, COD, TSS and color, has a high ability to receive and absorb water that flowed into the system, $1000-4000 \mathrm{Lm}^{-2} \mathrm{~d}^{-1}$ whereas conventional soil $10-40 \mathrm{Lm}^{-2} \mathrm{~d}^{-1}$, can prevent clogging and does not need -

\section{* Corresponding author}

Laboratory of Analytical Environmental Chemistry, Department of Chemistry, Faculty of Mathematics and Natural Sciences, Andalas University.

Padang 25163, Indonesia large area such as a pool treatment [2]. The MSL system constructed in Kasetsart University, Thailand, for food service wastewater treatment showed high removal rates of BOD $90 \%$, TN $70 \%$ and TP $90 \%$ for wastewater at a loading rate of $250 \mathrm{~L} / \mathrm{m}^{2} /$ day $[6]$.

From previous studies restaurant wastewater treatment with combination method of Grease Trap and Multi Soil Layering (MSL) has been studied. The highest efficiency for removal grease, nitrite, phosphate, nitrate on grease trap at flow rate of $25 \mathrm{~mL} / \mathrm{min}$ were equal to $95.40 \%, 12.91 \%$, $8.65 \%, 8.02 \%$ respectively and MSL could decreased of grease $100 \%$ both with aeration and non aeration for all flow rate. At a flow rate of $25 \mathrm{~mL} / \mathrm{min}$ with aeration, removal efficiency of nitrite $86.44 \%$, nitrate $92.53 \%$, phosphate $97.75 \%$, whereas in the non-aeration $64.21 \%$ nitrite, $83.98 \%$ nitrate and $79.75 \%$ phosphate [7], The efficiency of MSL system with composition volcanic soil, active carcoal, bagasse, iron powder (7.5:1:1:0.5) and zeolite in peat water treatment at flow rate of $5 \mathrm{mLmin}^{-1}$ is better, it could remove of color, COD, BOD, Organic content are 93.57\%; 90.48\%; $93.65 \%, 91.07 \%$ on aeration condition and $92.86 \% ; 89.52 \%$; $92.06 \% ; 89.005 \%$ on non aeration, while for $\mathrm{pH}$ could changed from 4.26 to 6.93 for aeration and 4.26 to 6.91 for non aeration [8]. The MSL system capable to remove the tartrazine dye of noodles wastewater with an efficiency were $76.86 \%$ and $82.14 \%$ in the conditions of aeration and non aeration at a loading rate of $10 \mathrm{~mL} \mathrm{~min}^{-1}$ [9].

The noodles wastewater consist of liquid organic waste based of raw materials processed from agriculture, such as wheat flour (contains carbohydrates, protein, vitamins, and minerals), palm oil (contains fatty acids include lauric, palmitic, oleic) and tartrazin dyes, dissolved in wastewater [9]. Tartrazine is also reputed to catalyze hyperactivity and other behavioral problems, asthma, migraine, thyroid cancer, etc. Because of its hazardous health effects, foods and drinks containing tartrazine are avoided [10]. In dealing with the waste generated in industrial, waste treatment noodles that have been used in some noodles industrial are using landfill system which needs large area and high operational cost.

In this study wastewater treatment of noodles industrial by using a MSL system with a composition of zeolite, volcanic soil from Mount Merapi of West Sumatera, Indonesian, coconut shell charcoal, sawdust, and the iron powder was investigated. The variations of the wastewater flow rate in the system were $10,20,40$, and $80 \mathrm{~mL} \mathrm{~min}^{-1}$ with two processes aeration and non-aeration conditions, the removal efficiency of phosphate, nitrite, nitrate, oil and grease were evaluated. 


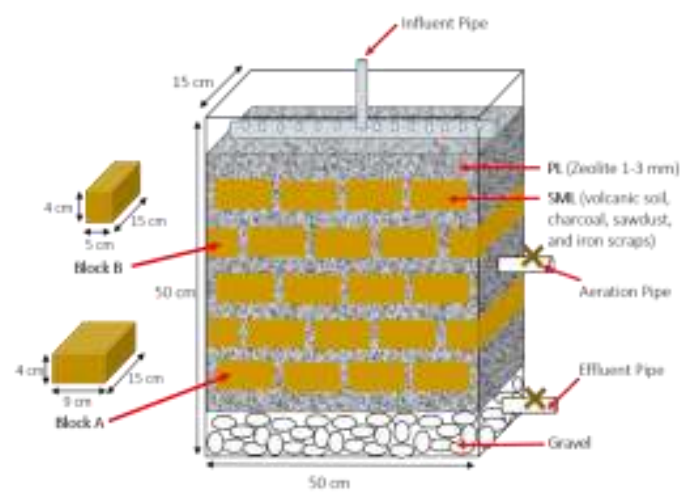

Figure 1. Design of MSL system [9].

\section{Materials and Methods}

\section{A. Materials of the MSL System}

The soil mixture layers of MSL system consist of materials, such as charcoal, sawdust, and iron scraps, were added to the volcanic soil (10:10:5:75) by dry weight, respectively, and the mixture is packed into gunnysacks. The permeable layers used zeolite $(1-3 \mathrm{~cm})$.

\section{B. Preparing the MSL System}

Fig. 1 shows the structure of the laboratory-scale MSL system used in the present study, these soil mixture blocks are placed into the MSL units in the form of an alternating brick layer-like pattern. Manner within the $50 \mathrm{~cm}(\mathrm{~L}) \times 15$ $\mathrm{cm}(\mathrm{W}) \times 50 \mathrm{~cm}(\mathrm{H})$ box made with acrylic, the SML blocks were prepared in two sizes. The blocks in the Block A group were $9 \mathrm{~cm}(\mathrm{~L}) \times 15 \mathrm{~cm}(\mathrm{~W}) \times 4 \mathrm{~cm}(\mathrm{H})$ in size, and those in the Block B group were $5 \mathrm{~cm}(\mathrm{~L}) \times 15 \mathrm{~cm}(\mathrm{~W}) \times 4 \mathrm{~cm}(\mathrm{H})$ in size.

An SML followed by a PL was repeatedly stacked in the acrylic box to form the MSL system. First, a5-cm-thick gravel arranged at the base of the box and then covered with plastic net then 5-cm-thick PL layer was paved followed by a 4-cm-thick SML layer. The horizontal intervals between the SML blocks were $2.5 \mathrm{~cm}$, and this interval was filled with the PL material. Next, a 4-cm-thick PL followed by a 4-cm-thick SML was repeatedly packed onto the base layer. Finally, a 5-cm-thick PL was packed at the top of the box to complete assembling the MSL system [9].

\section{Treatment of the Sample}

The wastewater of noodle industry was used to analysis of the quality wastewater parameters of $\mathrm{pH}$, phosphate, nitrite, nitrate, oil and grease. In order to predict the ability of the MSL system with performed analysis after treatment of noodle industry wastewater, loading rates were observed, 10, 20, 40, and $80 \mathrm{mLmin}^{-1}$ at aeration and non-aeration condition

\section{Monitoring Water Quality}

The Noodle Industry wastewater accumulated in the wastewater box and flowed through into the MSL system,. Some parameters such as $\mathrm{pH}$, phosphate, nitrate, nitrite, oil and grease were evaluated in the effluent to know the water quality [9].

\section{Results and Discussion}

\section{A. Characteristic of Noodle Wastewater}

The characteristics of noodle industry wastewater are shown as (INFLUENT) in Tab. 1. It seems that all parameter analysis is above the quality standard parameters of USEPA wastewater. Based on the characteristics of noodle industry wastewater, it is required for treatment. In this research variation of flow rate on aeration and non-aeration conditions in MSL system were evaluated. The effect of flow rate on concentration is shown in Tab.1. The smaller of flow rate will decrease the concentration parameter, contact between the wastewater and material in the MSL will be longer so that the purification process will be more optimal. Aeration system will be improved the reduction effluent concentration in each parameter analysis. Oxygen will increase the microorganism's activity present in the soil in degradation organic compounds contained in noodle wastewater.

TABEL.1. FLOW RATE EFFECT ON EFFLUENT CONCENTRATION THROUGHT MSL AERATION AND NON AERATION CONDITION

\begin{tabular}{|c|c|c|c|c|c|c|c|c|c|}
\hline \multirow{3}{*}{ PARAMETER } & \multirow{3}{*}{$\begin{array}{c}\text { INFLUENT } \\
(\mathrm{mg} / \mathrm{L})\end{array}$} & \multicolumn{8}{|c|}{ Concentration (mg/L) } \\
\hline & & \multicolumn{4}{|c|}{ AERATION } & \multicolumn{4}{|c|}{ NON AERATION } \\
\hline & & $\begin{array}{c}10 \\
m L \cdot \text { min }^{-1}\end{array}$ & $\begin{array}{c}20 \\
m L \cdot \text { min }^{-1}\end{array}$ & $\begin{array}{c}40 \\
\text { mL.min }^{-1}\end{array}$ & $\begin{array}{c}80 \\
m L . \text { min }^{-1}\end{array}$ & $\begin{array}{c}10 \\
\text { mL.min }\end{array}$ & $\begin{array}{c}20 \\
\text { mL.min }\end{array}$ & $\begin{array}{c}40 \\
m L . \text { min }^{-1}\end{array}$ & $\begin{array}{c}80 \\
\text { mL.min }\end{array}$ \\
\hline Tartrazine $^{\mathrm{a}}$ & 252 & 58.3 & 64.1 & 76.4 & 82.7 & 45 & 52.3 & 58.7 & 61.5 \\
\hline $\mathrm{T}-\mathrm{P}$ & 125 & 0.72 & 0.80 & 0.83 & 1.07 & 0.99 & 1.09 & 1.28 & 1.36 \\
\hline Nitrate & 8.03 & 1.625 & 2.375 & 3.063 & 3.667 & 2.333 & 2.833 & 3.271 & 3.979 \\
\hline Nitrite & 0.48 & 0.078 & 0.085 & 0.098 & 0.125 & 0.081 & 0.099 & 0.129 & 0.143 \\
\hline Oil and grease & 4 & 0 & 0 & 0 & 0 & 0 & 0 & 0 & 0 \\
\hline
\end{tabular}


Proc. of The Seventh Intl. Conf. On Advances in Applied Science and Environmental Technology - ASET 2017 Copyright (C) Institute of Research Engineers and Doctors, USA .All rights reserved.

ISBN: 978-1-63248-136-8 doi: 10.15224/ 978-1-63248-136-8-21

TABLE II. FLOW RATE EFFECT ON MSL SYSTEM EFFICIENCY OF NOODLE WASTEWATER TREATMENT BY AERATION AND NON AERATION CONDITION

\begin{tabular}{|c|c|c|c|c|c|c|c|c|}
\hline \multirow{3}{*}{ PARAMETER } & \multicolumn{8}{|c|}{ MSL System Efficiency (\%) } \\
\hline & \multicolumn{4}{|c|}{ AERATION } & \multicolumn{4}{|c|}{ NON AERATION } \\
\hline & $\begin{array}{c}10 \\
m L . \text { min }^{-1}\end{array}$ & $\begin{array}{c}20 \\
m L . \text { min }^{-1}\end{array}$ & $\begin{array}{c}40 \\
m L . \text { min }^{-1}\end{array}$ & $\begin{array}{c}80 \\
m L . \text { min }^{-1}\end{array}$ & $\begin{array}{c}10 \\
m L . \text { min }^{-1}\end{array}$ & $\begin{array}{c}20 \\
m L . \text { min }^{-1}\end{array}$ & $\begin{array}{c}40 \\
\text { mL.min }\end{array}$ & $\begin{array}{c}80 \\
\text { mL.min }\end{array}$ \\
\hline Tartrazine $^{\mathrm{a}}$ & 76.86 & 74.56 & 69.68 & 67.18 & 82.18 & 79.25 & 76.98 & 75.59 \\
\hline T-P & 99.43 & 99.36 & 99.33 & 99.14 & 99.21 & 99.13 & 98.98 & 98.91 \\
\hline Nitrate & 79.43 & 70.42 & 61.86 & 54.34 & 70.95 & 64.72 & 59.27 & 50.45 \\
\hline Nitrite & 83.65 & 82.18 & 79.45 & 73.79 & 83.02 & 79.25 & 72.96 & 70.02 \\
\hline Oil and grase & 100 & 100 & 100 & 100 & 100 & 100 & 100 & 100 \\
\hline
\end{tabular}

\section{B. The MSL System Efficiency of Noodle Wastewater Treatment}

The flow rate variations effect is very significant, because the impact of the contact time between the materials in the system MSL with noodle wastewater treated. The increase the contact time will increase the efficiency of the MSL and decrease contaminants in noodle wastewater. While giving aeration on MSL system did not affect too much, this is about $1-2 \%$ for each analysis parameter. This indicates that the amount of aerobic and anaerobic microorganisms in the system is not much different. The MSL efficiency to all parameters analysis conducted in the noodle wastewater treatment influenced by flow rate variations and aeration-non aeration condition can be shown in Tab. 2.

\section{C. pH Analysis}

Noodle industrial wastewater is containing organic compounds so that the organic acids in waste can make the $\mathrm{pH}$ became lower ( $\mathrm{pH} 4.23$ ). Noodle wastewater has been processed using MSL system obtained $\mathrm{pH} 8.25$ at a loading rate of $10 \mathrm{~mL} \mathrm{~min}^{-1}$ [9].

In Fig. 2, shows that the loading rate play an important role in changing the $\mathrm{pH}$ value of noodles industrial wastewater, where the slower of loading rate, the $\mathrm{pH}$ of the wastewater to be much improved from 4.23 to 8.25 .

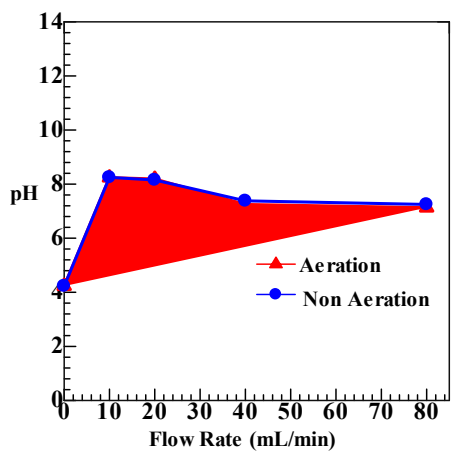

Figure 2. Effect of flow rate on $\mathrm{pH}$ of noodle wastewater

If the loading rate slower the contact times of wastewater will longer on the process denitrification by Nitrobacteria released hydroxyl ions which will raise the $\mathrm{pH}$ value [2]. According to Zein $\mathrm{R}$. et al, The $\mathrm{pH}$ of the effluent combination system of grease trap and MSL on the aeration slightly lower than non-aeration process due to nitrification possibility is greater than denitrification [7].
Nitrification is the process of oxidation organic compounds containing $\mathrm{N}$ (org- $\mathrm{N}$ ) into $\mathrm{NH}_{3}-\mathrm{N}, \mathrm{NH}_{3}-\mathrm{N}$ is then oxidized into $\mathrm{NO}_{2}-\mathrm{N}$ and $\mathrm{NO}_{3}-\mathrm{N}$ by aerobic bacteria. This process release $\mathrm{H}^{+}$ions that caused the $\mathrm{pH}$ of the effluent being lower than non-aeration process. While in the non-aeration process, $\mathrm{pH}$ of the effluent becomes greater than the effluent aeration, due to in the denitrification process $\mathrm{NO}_{2}-\mathrm{N}$ and $\mathrm{NO}_{3}-\mathrm{N}$ were reduced into $\mathrm{N}_{2}$ gas by releasing $\mathrm{OH}^{-}$ions [13].

\section{Removal Efficiency of Total Phosphorus (T-P)}

Total phosphorus is one of the important chemical parameter that determines, the T-P value in initial liquid influent data was obtained $125 \mathrm{mg} . \mathrm{L}^{-1}$. Fig..3. shows the values obtained in the optimum of total phosphorus removal efficiency of aeration and non aeration system were $99.43 \%$ and $99.21 \%$ at a flow rate of $10 \mathrm{~mL} \cdot \mathrm{min}^{-1}$. Soil mixture block contain iron particles which mix in soil to enhance the phosphate adsorption and denitrification functions act as reducing agents [2]. The value of the efficiency of T-P due to in the MSL system adsorption phosphorus layer of soil containing compounds of aluminum hydroxide occurs and also by the iron hydroxide formed from the addition of ferrous metals in the soil mix and this occurs in anaerobic conditions [12]. Phosphorus can be absorbed by the hydroxide of $\mathrm{Al}$ and $\mathrm{Fe}$ in the soil. Iron is added to the soil layer is converted to the ferrous ion $\mathrm{Fe}^{2+}$, which will move into the sieve and oxidized to the ferric ion $\mathrm{Fe}^{3+}$ which aims to decomposition $\mathrm{PO}_{4}^{3-}$ in wastewater [13].

Based on research by Masunaga [1], percentage of T-P decreased $63-89 \%$ by using the MSL system. MSL system is very effective in allowance due to the ability of the soil phosphate and iron powder as an absorbent or phosphate precipitation. With the aeration of the total phosphorus removed with the help of iron hydroxide in phosphate binding [13].

\section{E. Removal Efficiency of Nitrate}

Based on Fig. 4, the removal efficiency of nitrate (NO3$\mathrm{N})$ in the noodle wastewater using MSL system were $70.95 \%$ for aeration and $79.43 \%$ for non aeration at a flow rate $10 \mathrm{mLmin}^{-1}$. Nitrification is the aerobic oxidation process ammonium compounds into nitrate and nitrite catalyzed by microbial nitrification. Nitrification bacteria, among others: Nitrosomonas auropae and Nitrobacter spp [15]. 

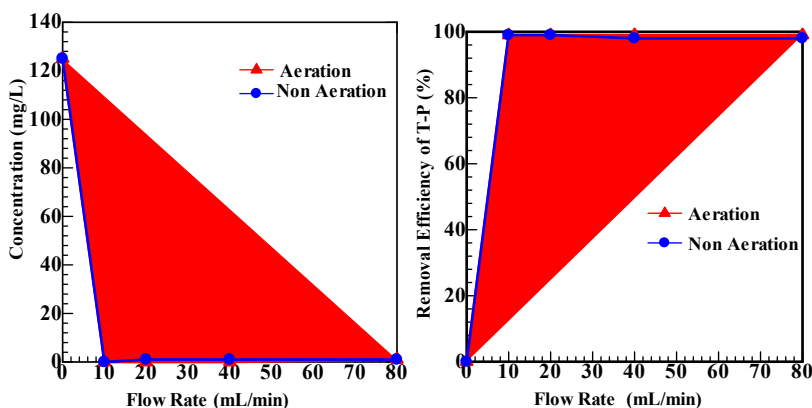

Figure 3. T-P removal concentration and efficiency of noodles wastewater after treated with aeration and non aeration MSL system
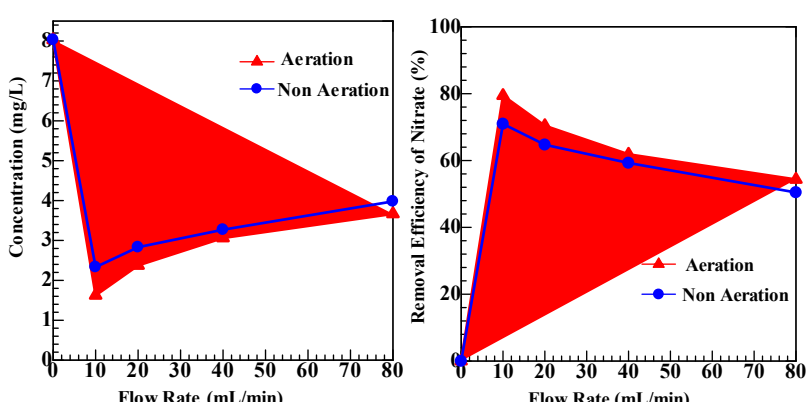

Figure 5. NO3-N removal concentration and efficiency of noodles wastewater after treated with aeration and non aeration MSL system

\section{F. Removal Efficiency of Nitrite}

Based on the Fig. 5, the removal efficiency Nitrite $(\mathrm{N}$ $\mathrm{NO}_{2}$ ) on the condition of aeration and non aeration were 83.65 and $83.02 \%$. Sato [11] conducted a water and purification wastewater to see a decrease Nitrite, where a reduction in the concentration of nitrite after processing with MSL system with varying sizes. This may be due to the system denitrification process occurs under anaerobic conditions where bacteria denitrification utilizing nitric compounds in the process of respiration which is then converted into nitrogen gas.

Aeration condition at the right level and the optimal duration significantly increases the elimination of Total Nitrogen (TN). However, excessive aeration has an adverse effect on the removal of TN by inhibiting the process of denitrification $[4,13]$.

In the MSL system, a block of soil mix with a bunch of sawdust and charcoal as a source of nutrition of the bacteria, so these bacteria work well in the process of denitrification in the MSL system. The nature of nitrite unstable, it is easy to turn into nitrates in the wastewater and it is also possible that the total ammonia is decomposed into nitrite in the nitrification few in number, so that nitrite produced become slightly $[3,14]$.

\section{G. Removal Efficiency of Oil and Grease}

Filtration and adsorption process plays a role in the allowance for oils and greases, especially the mixture of soil and zeolite. Edwin [16] in his research said that the removal efficiency of oil and fat in the MSL system 1 (layer of soil mix Andisols and charcoal) ranged from 27.778 to $89.474 \%$ and the MSL system 2 (layer of soil mix Andisols with
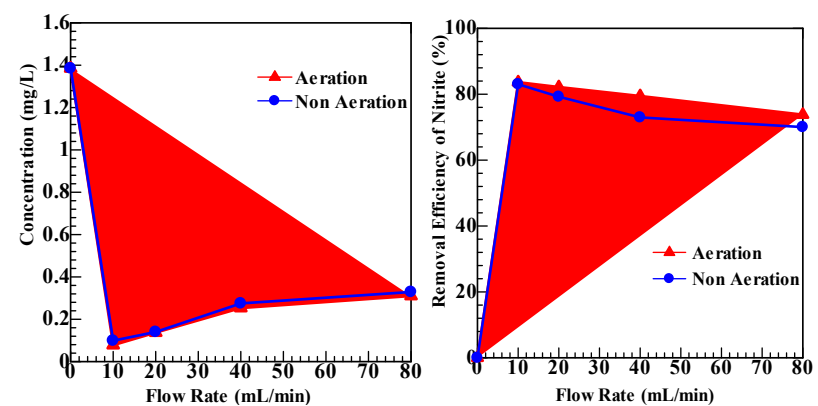

Figure 4. $\mathrm{NO}_{2}-\mathrm{N}$ removal concentration and efficiency of noodles wastewater after treated with aeration and non aeration MSL system
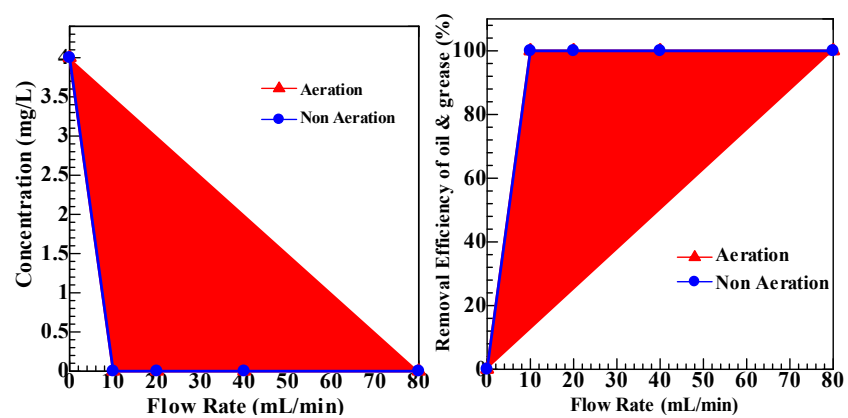

Figure 6. Oils and grease removal concentration and efficiency of noodles wastewater after treated with aeration and non aeration MSL system

sawdust) ranged from 23.810 to $62.500 \%$, it can be concluded that the removal efficiency of oil and greases shown to be affected mixture of soil and organic material on a layer of anaerobic system.

\section{Conclusion}

The MSL system that was constructed has contributed in decreasing levels of phosphate, nitrite, nitrate, oil and grease at flow rate $10 \mathrm{~mL} \cdot \mathrm{min}^{-1}$ and raising the $\mathrm{pH}$ of the Noodle Industry wastewater with aeration and non aeration condition.

\section{Acknowledgment}

The authors would like to thank to Directorate General of Higher Education, Ministry of Research, Technology and Higher Education, which has funded this study in accordance with the Agreement on Implementation of Leading "Higher Education Grant Number: 23/UN.16.17/PP.HGB/LPPM/2017”.

\section{References}

[1] T. Masunaga, K. Sato, M. Shirahama, H. Kudo, T. Wakatsuki. "Characteristic of Wastewater Treatment using a Multi-Soil-Layering System in Relation to Wastewater Contamination Levels and Hydraulic Loading Rates". Soil Sci. and Plant Nut, vol. 53, pp. 215223, 2007.

[2] S. Luanmanee, P. Boonsook, T. Attanandan, B. Saitthiti, C. Panichajakul, and T. Wakatsuki. "Effect of Intermittent Aeration Regulation of a Multi-Soil-Layering System on Domestic Wastewater Treatment in Thailand”. Eco. Eng, vol. 18 (4), pp. 415-428, 2002.

[3] T. Wakatsuki, H. Esumi and S. Omura. "High performance and N \& P removable on-site domestic wastewater treatment system by MultiSoil-Layering method". Water Sci. Technol., vol. 27 (1), pp. 31-40, 1993. 
[4] X. Chen, AC Luo, K. Sato, T. Wakatsuki, T. Masunaga. "An Introduction of a Multi- Soil-Layering System: A Novel Green Technology for Wastewater Treatment in Rural Areas". Water and Environ. J, vol. 23, pp. 255-265, 2009.

[5] S. Ying, YT. Huang, HF. Ji, XJ. Nie, ZY. Zhang, C. Ge, AC. Luo, X Chen. "Treatment of turtle aquaculture effluent by an improved multi-soil-layer system". J of Zhejiang University. Sci. B, vol. 16 (2), pp. 145-154, 2005.

[6] T. Attanandana, B. Saitthiti, S. Thongpae, S. Kritapirom, S. Luanmanee, T. Wakatsuki. "Multi-Media-Layering System for Food Service Wastewater Treatment", Eco. Eng, vol. 15, pp. 133-138, 2000

[7] R. Zein, R. Suhaili, L. Novita, Mukhlis, S. Ningsih, N. Swesty, H. Novrian. "Novel two stage vertical flow biofilter system for efficiency treatment of restaurant wastewater" Research $\mathbf{J}$ of Pharm. Bio and Chem . Sci. (RJPBCS), vol. 7(5), pp. 71-79, 2016.

[8] R. Zein, Mukhlis, N. Swesti, L. Novita, E. Novrian, S. Ningsih, and Syukri. "Peat Water Treatment by Using Multi Soil Layering (MSL) Method" Der Pharma Chemica, vol. 8(12), pp. 254-261, 2016.

[9] R. Zein, Zilfa, S. Ningsih, L. Novita, N. Swesty, Mukhlis, and H. Novrian. "Treatment of Waste water Noodle Industry with a MultiSoil-Layering (MSL) System" Research J of Pharm. Bio and Chem Sci. (RJPBCS), vol. 7(6), pp. 88-94, 2016

[10] R. Zein, S. Fauzia, F. Furqani, E. Munaf. "Adsorption and Reaction Kinetics of Tartrazine by using Annona muricata L Seeds". J. of Chem. and Pharm. Research., vol. 7(1), pp. 573-582, 2015.

[11] K. Sato, N. Iwashima, T. Wakatsuki, T. Masunaga. "Quantitative evaluation of treatment processes and mechanisms of organic matter, phosphorus, and nitrogen removal in a multi soil layering system". Soil Sci. and Plant Nut, vol. 57, pp. 475-486, 2011.

[12] K. Sato, T. Wakatsuki, T. Masunaga. "Characterization of Treatment Processes and Mechanisms of COD, Phospous, Nitrogen Removsl in s Multi Soil Layering System” Soil Sci. and Plant Nut, vol. 51, pp. 213 221, 2005.

[13] P. Boonsook, S. Luanmanee, T. Attanandana, A. Kamidouzono, T. Masunaga, T. Wakatsuki. "A Comparative Study of Permeable Layer Materials and Aeration Regime on Efficiency of Multi-Soil-Layering System for Domestic Wastewater Treatment in Thailand (Environment)". J of Soil Sci. and Plant Nut, vol. 49 (6), pp. 873-882, 2003.

[14] S. Luanmanee, T. Attanandana, T. Masunaga, T. Wakatsuki. "The Efficiency of a Multi-Soil-Layering System on Domestic Wastewater Treatment During the Ninth and Tenth Years of Operation". Eco Eng vol. 18(20), pp. 185-199, 2001.

[15] M. Wagner, A. Loy. "Bacterial community composition and function in sewage treatment systems". Opinion Biotechnol, vol. 13(3), pp. 218-227, 2002

[16] Edwin, Tivany. "Efisiensi dan Absorption capacity and effeciency of Fly Ash as oil and fat removal from Hotel wastewater by Multi Soil Layering (MSL) system". J of Environ Eng UNAND, vol. 10 (1), pp. 38-45, 2013.

\section{About Author (s):}

\begin{tabular}{|l|l|}
\hline Refilda is associate professor at \\
Department of Chemistry, Faculty of \\
Mathematics and Natural Sciences, \\
Andalas University, Padang, West \\
Sumatra, Indonesia.
\end{tabular}

